\title{
Potato Cyst Nematodes Globodera SPP. IN THE BEKAA VALLEY, LEBANON
}

\author{
Sleiman Kachacha ${ }^{1}$, Said K. Ibrahim ${ }^{1, *}$, Georges Kachacha ${ }^{2}$, Loudmilla Ibrahim ${ }^{1}$, \\ Fouad Jreijiri $^{3}$, Toufic Elbeaino ${ }^{4}$ and Elia Choueiri ${ }^{3}$ \\ ${ }^{1}$ Faculty of Agricultural Sciences, Lebanese University, Beirut, Lebanon \\ ${ }^{2}$ Natural Sciences Department, Faculty of Sciences 2, Lebanese University, Fanar, \\ Lebanon \\ ${ }^{3}$ Department of Plant Protection, Lebanese Agricultural Research Institute, Tal Amara, \\ P.O. Box 287, Zahlé, Lebanon \\ ${ }^{4}$ Istituto Agronomico Mediterraneo di Bari, Via Ceglie 9, 70010, Valenzano, Bari Italy \\ *Author for correspondence: Said Ibrahim \\ sibrahim58@yahoo.com
}

(Received January 2020 - Accepted June 2020)

\begin{abstract}
Kachacha, S., Ibrahim, S., Kachacha, G., Ibrahim, L., Jreijiri, F., Elbeaino, T., Choueiri, E. (2020). Potato Cyst nematodes Globodera spp. in the Bekaa valley, Lebanon. Lebanese Science Journal, 21(1), 54-64.

Our study was conducted in Bekaa area (Lebanon) to determine the presence and distribution of the potato cyst nematode, Globodera spp. A total of 80 soil samples were collected from 30 different areas. The overall egg counts revealed that 39 (79.6\%) out of 49, cyst affected soil samples, collected contained eggs. In Zahlé, the count of nematodes in the soil samples revealed that 9 out of 11 samples tested (81.8\%) contained cysts nematodes, but only 7 (77.7\%) of the cyst contained eggs. The level of infestation of soil sample ranged between 0 and 5.3 eggs $/ g$ soil. No nematodes infection was detected in samples collected from Aana, Kamed El Laouz, Kefraya and Khiara. The identity of a newly discovered population of potato cyst nematode Globodera pallida associated with potato in West Bekaa was established by molecular methods. A set of three polymerase chain reaction (PCR) primers readily identified the presence of $G$. rostochiensis and $G$. pallida from field samples. The origin of this infestation is unknown. The results of the occurrence and distribution of Globodera spp in each area are discussed.
\end{abstract}

Keywords: Bekaa valley, Cyst nematodes, Globodera, egg, PCR, potato, rDNA.

\section{INTRODUCTION}

Plant-parasitic nematodes cause significant economic losses in a wide variety of horticultural, agricultural and forest systems (Potter \& Olthof, 1993). Potato crops can be severely damaged by the two potato cyst nematodes, (PCN) Globodera rostochiensis (Wollenweber, 1923; Skarbilovich, 1959) and G. pallida (Stone, 1973). It has been estimated that in UK the PCN cause yield losses around $£ 50$ million (about $\$ 82$ million) per year (CABI, 2013) or about $9 \%$ yield loss of annual national production. Within the 
European Union, the annual estimated loss is costing $€ 300$ million. The cyst nematodes infestations are known to occur in several countries, especially in cooler areas of subtropical and tropical regions, as well as temperate regions of the world (EPPO, 2004) with significant potential to reduce potato tuber yields up to $80 \%$ in heavily infested and uncontrolled fields (Spears, 1968). Barker and Koenning (1998) revealed that yield losses incurred by $G$. rostochiensis susceptible potato averaged $38 \%$ compared to $18.3 \%$ in resistant potato variety. Cysts containing up to 500 eggs can survive in soil for over 15 years in the absence of a host crop (Jones et al., 1998), and over 28 years in dormant stage (Baldwin \& Mundo-Ocampo, 1991). In Lebanon, today, there is no estimate of the monetary damage caused by PCN. However, several species of nematodes are also considered as the major limiting factors of potato production. In a survey of plant parasitic nematodes conducted during 1970's (Taylor, et al., 1972), PCN was not found in Lebanon. However, a study conducted in 2000 in Rayak area reported the discovery of potato cyst nematodes for the first time (Ibrahim et al., 2000). A number of immunological, protein and DNA-based techniques can distinguish between $G$. rostochiensis from $G$. pallida (reviewed by Fleming and Powers (1998), and Ibrahim et al., (2001)). The PCR test confirmed the presence of PCN as G. rostochensis species (Ibrahim et al., 2000). Neither G. pallida species nor pathotypes were detected (Ibrahim et al., 2000). The source of Globodera spp in Lebanon is not known (Taylor et al., 1972; Ibrahim et al., 2000), establishing its distribution within the potato growing area, however, is essential. Since the survey was conducted over 20 years ago and on a small scale (Rayak), the presence of the G. pallida cannot be ruled out especially that the distribution of G. rostochiensis and G. pallida is worldwide and they rarely occur alone but more often in combination in one field. A survey carried out in the UK revealed that PCN were present in $64 \%$ of sites sampled. Of the populations found, $66 \%$ were G. pallida, $8 \%$ were G. rostochiensis and $26 \%$ contained both species (Ibrahim et al., 2001; Minnis et al., 2002).

The PCR technique offers the prospect of a simple, rapid and reliable diagnostic tool for plant parasitic nematodes, which will enable to identify and quantify populations of PCN from field samples (Burrows and Perry, 1988; Stratford et al., 1992; Ibrahim et al., 1997 and 2001; Bates et al., 2002).

The main objectives of this study were: 1) to determine the relative distribution of potato cyst nematodes in Bekaa valley; 2) to quantify the population level in field soil samples and 3) to determine species identification using PCR techniques.

\section{MATERIAL AND METHODS}

\section{Soil sampling}

Potato cultivation in Lebanon is mainly concentrated in the Bekaa valley (central eastern Lebanon) at 900-1000 m a.s.1. (70 \% of total potato cultivated area), and the Akkar plain (northern Lebanon, 25-30 \% of total potato cultivated area). The current work focused on the Bekaa valley region where potatoes at each season are produced in two cycles: summer potatoes (spring-summer cycle) and late potatoes (summer-autumn cycle). Extensive sampling was conducted between June and November 2017 in the Bekaa valley to carry out official inspections and sampling during each growing cycle of this season (Figure 1). 


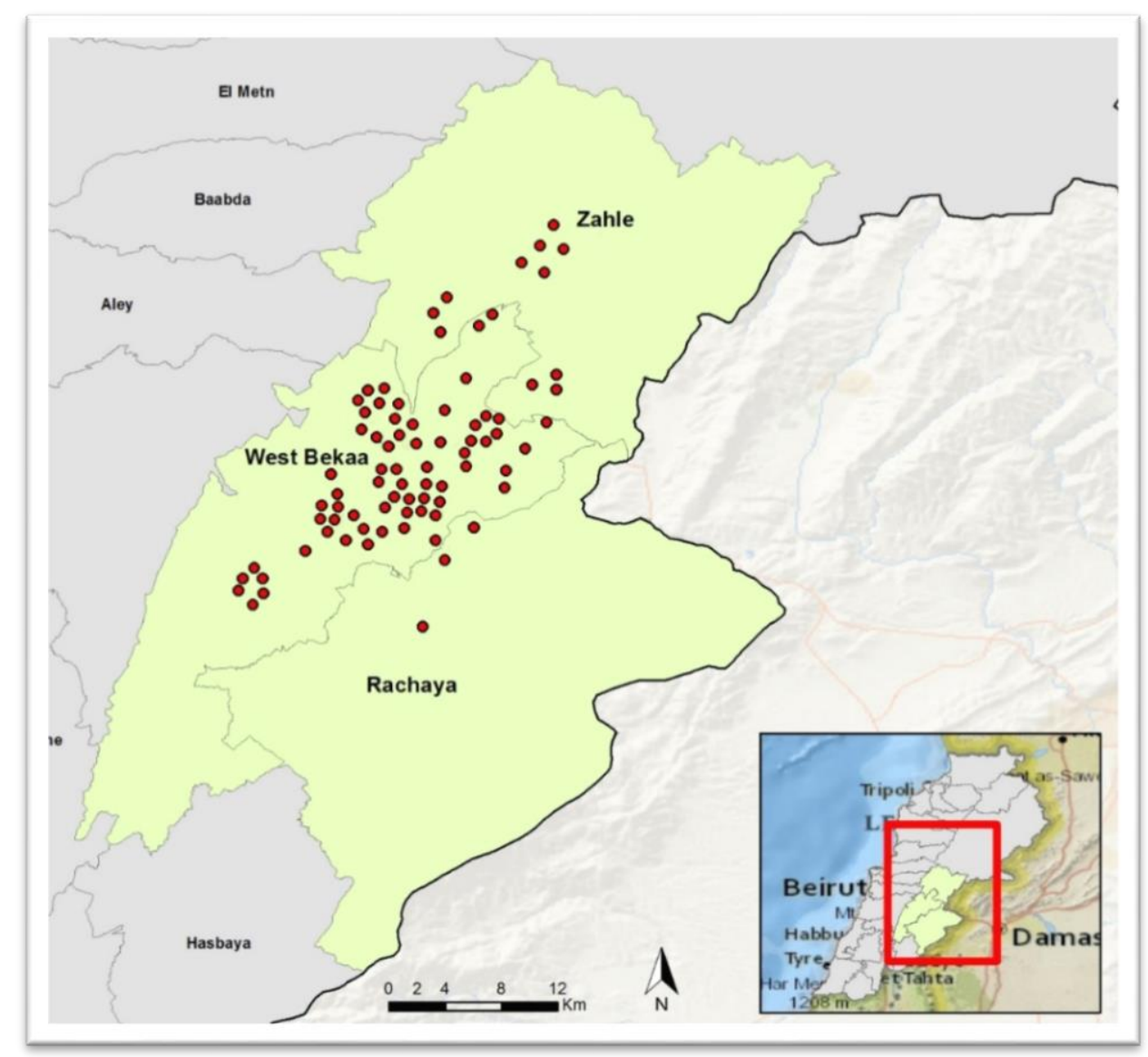

Figure 1. Map of Lebanon showing sampled areas (in yellow color).

A total of 80 fields were selected from 30 different areas in Zahlé, West Bekaa and Rachaya districts (Table 2). Fields were representing farms with land $>10$ ha for summer potatoes and late potatoes crops. The fields names cited in table (2) are taken from the Official Guide for the real estate areas, cities and villages of Lebanon. For traceability, GPS coordinates of sampled fields were recorded using Garmin Trex®. Samples were collected using a "cheese-corer"' style auger with a half-cylindrical blade. Soil samples consisting of approximate 50 cores $(2.5 \times 20 \mathrm{~cm})$ were collected from each field at a depth of $20-30 \mathrm{~cm}$ in ' $Z$ '" pattern and bulked together to give approximately 1$2 \mathrm{~kg}$ of soil. Soil samples were labeled and stored at $20-22^{\circ} \mathrm{C}$ for cyst extraction.

\section{Cyst extraction, detection and content estimation}

The soil samples were air-dried, and cysts were extracted using a modified container based on the Fenwick can technique (Fenwick, 1949). Each soil sample was thoroughly mixed, and a $200 \mathrm{~g}$ sub-sample was weighed, and the cysts were extracted. The tank was filled with water before the sample was introduced. The sample was stirred with a plastic rod for 2-3 minutes. Cysts were then collected in sieves and transferred into muslin, labeled and left to dry. The number of cysts and their content were estimated by standard methods (Southey, 1986). The PCN cysts present in each extract were counted under a stereomicroscope and 50 cysts (all cysts if there were less than 50) were removed for egg estimation before crushing. The PCN cysts were soaked in water overnight and the eggs were counted in $1 \mathrm{ml}$ aliquots from the resulting suspension. The population 
density (eggs/g) of dried field soil was calculated for each sample in which PCN was found. Samples that contained cysts other than Globodera species were noted (results not shown).

\section{DNA Extraction}

DNA was extracted following the protocol of Bulman and Marshall (1997) with modifications. The remnant cysts from the egg counts were used as a source of DNA template for the PCR reactions. Cysts were soaked in water for 24 hours and then sorted in 12 lots (Table 1). In Eppendorf tubes, the cysts in each lot were grounded using plastic micro-pestles (Treff), with $200 \mu \mathrm{l}$ solution 5M guanidine isothiocyanate, $10 \mathrm{mM}$ EDTA, $50 \mathrm{mM}$ Tris- $\mathrm{HCl}(\mathrm{pH} 7.5)$, and 2\% Sodium Metabisulfite. After room temperature incubation for up to 1 hour and centrifugation for $15 \mathrm{~min}$ at $10000 \mathrm{rpm}$ at $4^{\circ} \mathrm{C}$, the supernatant was collected and then, was mixed with half its volume with phenol and chloroform. This mixture was first vortex for 1 minute then, centrifuged at $10000 \mathrm{rpm}$ for 5 minutes at $4{ }^{\circ} \mathrm{C}$. The supernatant was collected and mixed with Ethanol and $0.1 \times \mathrm{V}$ of sodium acetate, and repeated three times. The supernatant was removed, and the DNA was eluted and resuspended in $100 \mu \mathrm{l}$ of $\mathrm{H}_{2} \mathrm{O}$ sterile.

Table 1. DNA sampling procedure.

\begin{tabular}{|l|l|}
\hline Lot number & Number of cysts \\
\hline $\mathbf{1}$ & 2 \\
\hline $\mathbf{2}$ & 4 \\
\hline $\mathbf{3}$ & 6 \\
\hline $\mathbf{4}$ & 8 \\
\hline $\mathbf{5}$ & 10 \\
\hline $\mathbf{6}$ & 2 \\
\hline $\mathbf{7}$ & 4 \\
\hline $\mathbf{8}$ & 6 \\
\hline $\mathbf{9}$ & 8 \\
\hline $\mathbf{1 0}$ & 10 \\
\hline $\mathbf{1 1}$ & 20 \\
\hline $\mathbf{1 2}$ & 20 \\
\hline
\end{tabular}

\section{Polymerase chain reaction and PCR primer}

Polymerase chain reaction technique was applied to identify different of PCN species present in soil samples. The ribosomal gene spacer region was amplified using primers ITS5 (White et al., 1990) and ITS26 (Howlett et al., 1992). To distinguish between $G$. rostochiensis and G. pallida, PCR reactions were carried out using primers PITSr3 (5'-AGCGCAGACATGCCGCAA-3') and PITSp4 (5'ACAACAGCAATCGTCGAG-3') in combination with universal primer ITS5 (White et al., 1990). PCR concentration were $5 \mu 110^{*}$ Buffer Promega (Guanidine thiocyanate + EDTA + Tris-HCl), $25 \mathrm{mM} \mathrm{MgCl}_{2}, 10 \mathrm{mM}$ each dNTP, $10 \mu \mathrm{M}$ each primer, and $0.25 \mu \mathrm{l}$ 
Taq DNA polymerase (Life Technologies). Reactions were run for 35 cycles of $94^{\circ} \mathrm{C}(30$ s), $55^{\circ} \mathrm{C}(30 \mathrm{~s}), 72^{\circ} \mathrm{C}(2 \mathrm{~min})$ and $72^{\circ} \mathrm{C}(5 \mathrm{~min})$, with an initial denaturation of $94^{\circ} \mathrm{C}$ for 2 min. All PCR reactions included a no DNA control were performed on a Perkin Elmer 2400 thermal cycler.

\section{Agarose gel electrophoresis}

PCR products were separated on $1.2 \%$ agarose gel buffered in $1 \mathrm{X}$ TBE, containing $0.02 \mu \mathrm{g} / \mathrm{ml}$ ethidium bromide. DNA was visualized under UV light and records made with a digital camera attached to a Gel Doc-1000 box (Bio-Rad Ltd).

\section{RESULTS}

\section{Distribution of PCN in different regions of Bekaa Valley}

Cysts were collected almost from all extracted samples (80 samples) and the results of the standard counts tests are presented in Table (2). The results showed that the range of cyst in collected samples was varying from one area to another. The egg counts revealed that not all the cyst contained eggs. The highest level was detected in West Bekaa in comparison to Zahlé, whereas, the lowest level of infection was discovered in Rachaya. Most of the collected cysts from this area where empty from eggs. This could be related to the intensive use of nematicides.

The level of distribution (infestation) of PCN in the collected soil samples from different areas is presented in Table 2. In West Bekaa, a total of 66 soil samples were collected where $49(74.2 \%)$ were infected with nematodes. The results of the egg counts showed that 39 (79.6\%) out of 49 soil samples had contained eggs (Table 3). In Zahlé, the count of nematodes in the soil samples revealed that 9 out of 11 samples tested $(81.8 \%)$ contained cysts nematodes, but 7 (77.7\%) of the cyst contained eggs (Table 3.). The level of infestation was varying from one area to another. The highest level was detected in Zahlé (3.4 eggs/1g soil), whereas, the lowest level of infection was detected in Kab Elias (1.9 eggs/1g soil) (Table 2). The level of infestation of soil sample ranged between 0 and $5.3 \mathrm{eggs} / \mathrm{g}$ soil. The level of infestation with nematodes population varied from one area to another. The highest level was observed in Lousia (5.3 eggs/g soil) and Ghazzeh (3.8 eggs/g soil). No nematodes infection was detected in sample collected from Aana, Kamed El Laouz, Kefraya and Khiara. The average infestation in the area revealed 2.1 eggs/g soil. Moreover, two samples from Rachaya (Bireh and Rafid) were not infected with nematodes. Only sample collected from Baaloul area contained cysts with viable eggs with a population density of $1.1 \mathrm{eggs} / \mathrm{g}$ soil. The highest mean of cyst nematode was detected in West Bekaa compared to the other regions. Other cysts nematodes (Heterodera spp) were discovered in some soil samples, that could be confused in appearance with PCN but were not considered in this study. 
Table 2. Distribution and Infestation Level of the Potato Cyst Nematodes Globodera spp. in the Bekaa Valley.

\begin{tabular}{|c|c|c|c|c|c|c|}
\hline Region & Area & $\begin{array}{l}\text { Number of } \\
\text { soil samples } \\
\text { tested }\end{array}$ & $\begin{array}{l}\text { Number of soil } \\
\text { samples } \\
\text { containing cysts }\end{array}$ & $\begin{array}{l}\text { Number } \\
\text { of cysts/g } \\
\text { soil }\end{array}$ & $\begin{array}{l}\text { Number of soil } \\
\text { samples } \\
\text { containing eggs }\end{array}$ & $\begin{array}{l}\text { Number } \\
\text { of eggs/g } \\
\text { soil }\end{array}$ \\
\hline \multirow{22}{*}{$\begin{array}{l}\text { West } \\
\text { Bekaa }\end{array}$} & Aammiq & 6 & 4 & 0.0125 & 2 & 1.4 \\
\hline & Aana & 1 & $\mathbf{0}$ & $\mathbf{0}$ & $\mathbf{0}$ & $\mathbf{0}$ \\
\hline & Ain Zebdeh & 1 & 1 & 0.085 & 1 & 2.3 \\
\hline & Dakoueh & 8 & 6 & 0.1 & 4 & 3.5 \\
\hline & El Marej & 1 & 1 & 0.07 & 1 & 1.9 \\
\hline & Ghazzeh & 2 & 2 & $\mathbf{0 . 0 3 7 5}$ & 2 & 3.8 \\
\hline & $\begin{array}{ll}\text { Haouch } & \text { El } \\
\text { Harimeh } & \end{array}$ & 1 & 1 & 0.025 & 1 & 2.6 \\
\hline & Joubb Jannine & 4 & 3 & 0.08 & 2 & 2.3 \\
\hline & $\begin{array}{ll}\text { Kamed } & \text { El } \\
\text { Laouz } & \\
\end{array}$ & 3 & $\mathbf{0}$ & $\mathbf{0}$ & $\mathbf{0}$ & $\mathbf{0}$ \\
\hline & Kefraya & 1 & $\mathbf{0}$ & $\mathbf{0}$ & $\mathbf{0}$ & $\mathbf{0}$ \\
\hline & Khiara & 2 & $\mathbf{0}$ & 0 & $\mathbf{0}$ & $\mathbf{0}$ \\
\hline & $\begin{array}{l}\text { Khirbet } \\
\text { Qanafar }\end{array}$ & 1 & 1 & 0.015 & 1 & 1.9 \\
\hline & Lala & 1 & 1 & 0.0055 & 1 & 2.1 \\
\hline & Loussia & 10 & 10 & 0.4425 & 8 & 5.3 \\
\hline & $\begin{array}{l}\text { Manara, } \\
\text { Hammara }\end{array}$ & 1 & 1 & 0.1 & 1 & 2.7 \\
\hline & Mansoura & 10 & 6 & 0.012 & 5 & 3.1 \\
\hline & Nabi Zraiq & 1 & 1 & 0.03 & 1 & 3.3 \\
\hline & Qaraaoun & 1 & 1 & 0.075 & 1 & 2.2 \\
\hline & Saghbine & 3 & 3 & 0.0316 & 2 & 1.8 \\
\hline & Saouiri & 2 & 2 & 0.0225 & 2 & 3.6 \\
\hline & $\begin{array}{l}\text { Soultan } \\
\text { Yaaqoub }\end{array}$ & 4 & 4 & 0.1475 & 3 & 2.9 \\
\hline & Tall Znoub & 2 & 1 & 0.0225 & 1 & 1.5 \\
\hline \multirow[t]{3}{*}{ Rachaya } & Bireh & 1 & 1 & 0.015 & $\mathbf{0}$ & 0 \\
\hline & Baaloul & 1 & 1 & 0.04 & 1 & 1.1 \\
\hline & Rafid & 1 & 1 & 0.025 & $\mathbf{0}$ & 0 \\
\hline \multirow[t]{4}{*}{ Zahlé } & Anjar & 1 & 1 & 0.165 & 1 & 2.8 \\
\hline & $\begin{array}{l}\text { Majdel } \\
\text { Aanjar }\end{array}$ & 2 & 2 & 0.085 & 2 & 2.4 \\
\hline & Kab Elias & 3 & 2 & 0.015 & 1 & 1.9 \\
\hline & Zahlé & 5 & 4 & 0.022 & 3 & 3.4 \\
\hline Total & 30 & 80 & 61 & & 47 & \\
\hline
\end{tabular}


Table 3. The main distribution of cysts nematodes infestations in the different regions of Bekaa valley.

\begin{tabular}{|l|l|l|l|l|l|}
\hline Region & $\begin{array}{l}\text { Number of } \\
\text { samples } \\
\text { tested }\end{array}$ & $\begin{array}{l}\text { Number of } \\
\text { samples } \\
\text { containing cysts }\end{array}$ & $\begin{array}{l}\text { \% of samples } \\
\text { containing } \\
\text { cysts }\end{array}$ & $\begin{array}{l}\text { Number of } \\
\text { samples } \\
\text { containing eggs }\end{array}$ & $\begin{array}{l}\text { \% of samples } \\
\text { containing } \\
\text { eggs }\end{array}$ \\
\hline West Bekaa & 66 & 49 & 74.2 & 39 & 79.6 \\
\hline Rachaya & 3 & 3 & 100 & 1 & 33.3 \\
\hline Zahlé & 11 & 9 & 81.8 & 7 & 77.7 \\
\hline
\end{tabular}

The population densities of PCN are presented in figure 2 and expressed in eggs/g soil. The most common population density range was $2-3$ eggs/g soil (32\% of infested sites). Only $4 \%$ of infested sites showed the highest population density (5> eggs/g soil) whereas, the lowest population density ( $>1$ eggs/ g soil) were revealed in $20 \%$ of the infested sites (Figure 2).

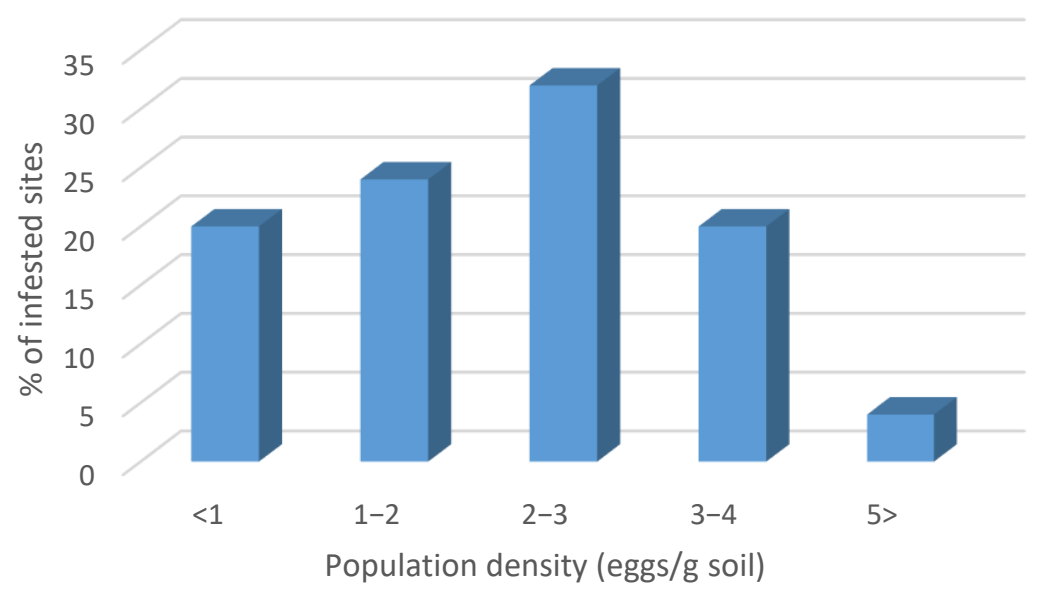

Figure 2. The percentage of infested sites with different PCN population densities (eggs/g soil).

\section{Molecular identification}

The species of PCN were determined in each sample that was found to contain eggs. Twelve lots were identified using PCR techniques. The PCR amplification was successful using crude DNA of single or bulk nematodes as templates. In combination, the species-specific primers of G. pallida (PITSp4) and G. rostochiensis (PITSr3) and the ITS5 primer readily differentiated between all the populations tested from Lebanon (White et al., 1990). G. rostochiensis had a PCR product of 434 bp using PITSr3 primer, whereas G. pallida showed 265with PITSp4 primer. As a result, G. pallida was detected in most of the tested lots (lot 1,5,6,7, 9, 10, 12), whereas $G$. rostochiensis in lots 1, 7, 9, and 10. However, both species were found as a mixture in lots 1and 10. No PCR reaction was detected in lots 2, 3, 4 and 8 (Figure 3). 

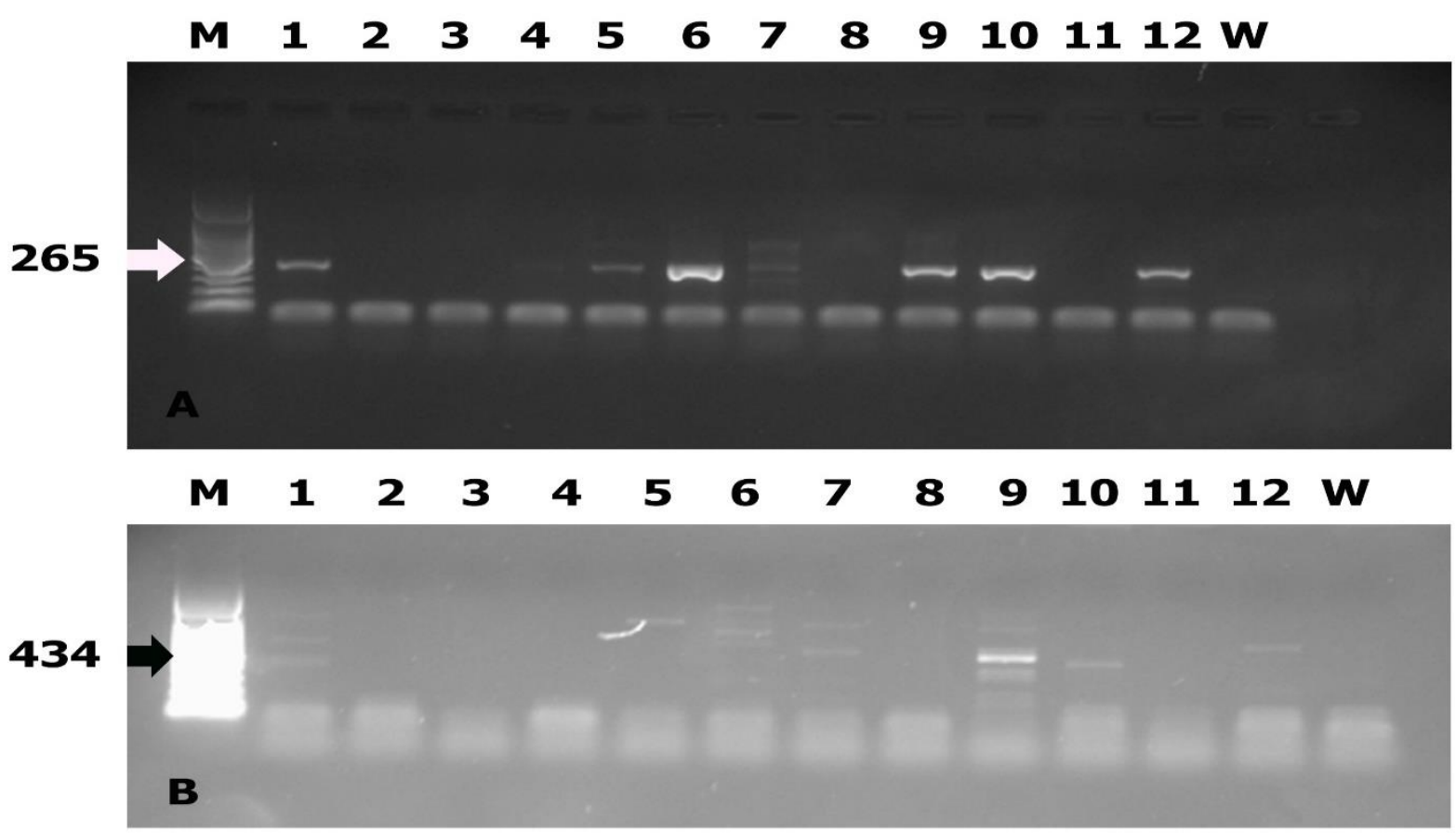

Figure 3. PCR differentiation of the potato cyst nematodes; A: G. pallida (Pa), and B: Globodera rostochiensis (Ro): M: molecular marker, W-negative control.

\section{DISCUSSION}

The occurrence and the spatial distribution of potato cyst nematodes in the Bekka Valley have been studied. This figure is significantly higher than $17 \%$ of contamination rate received in the last survey (Ibrahim et al., 2004), indicating a significant increase in distribution. The population level in the sampled areas varied from one area to another. The results revealed that $81.8 \%$ of Zahlé samples contained PCN but only about $77.7 \%$ contained eggs. Whereas in West Bekaa area, PCN were detected in $74.2 \%$ of collected samples with higher level of egg content. Rachaya stands as the less infected area by nematode and where the infection remains in its primitive stage. The difference of infestation level among the areas could be due to several factors, such as cultural practice type or absence of crop rotation, use of susceptible cultivars, different soil types and chemical application. However, there are a tendency for late potatoes production to be severally infected by cyst nematode than summer potatoes from the same area. This could be related most probably to infected tubers coming from different region by the end of the season in summer.

The population densities of PCN is significantly higher than $11 \%$ of the last survey (Ibrahim et al., 2017), while the most common population density range is 2-3 eggs/g soil (32\% of infested sites). As potato production has become more specialized and there is reduction in the number of growers, it has been concentrated on a smaller area of land, especially in the Anti-Lebanon area, resulting from shorter rotations, which have encouraged build-up of PCN infestations. Discussions with growers from Loussia, Ghazeh and Dakoueh indicated that they were unaware of the nematodes presence. Repeated potato production on the same field might have contributed to the accumulation of high PCN levels leading to the yield losses. In addition, the sugar beet production has 
become very restricted or even absent forcing the growers to shift to potato production. Potato production has been carried out all over the Bekaa plain, Akkar, Marjayoun as well as in certain localities in Mount Lebanon without crop rotations. This may explain the build-up of PCN infestation and the risks of farther expansion. Also, there are other factors that may contribute to this large distribution of PCN in Lebanon, such as the use of susceptible varieties, contamination of equipment, uncertified cultivars or seeds, soil type, irrigation methods and absence of quarantine.

The distribution of G. pallida and G. rostochiensis is worldwide and they rarely occur as separate species but more often as a mixture species in one field (Ibrahim et al., 2000, 2001, 2004; Minnis, et al., 2002). The species identification by PCR method in this study showed G. rostochiensis present in the soil samples tested in agreement with the earlier reports (Ibrahim et al., 2000, 2004). Moreover, this study reported for the first time the occurrence of Globodera pallida in Lebanon and in more than one sample. In the previous surveys only G. rostochiensis were detected in Lebanon (Ibrahim et al., 2000 and 2004). A small proportion of potato growing land in the Lebanon has been sampled and, in fields that have been infested relatively recently containing unevenly distributed populations, the probability of detecting cysts in a soil sample is low (Haydock and Evans, 1998). In the contrary, a survey carried out in England and Wales revealed that G. pallida was the dominant species in the field samples tested (Ibrahim et al., 2001). The PCR results indicated that $66 \%$ of field samples contained pure G. pallida, $8 \%$ contained pure G. rostochiensis and 26\% found mixtures of the two species (Ibrahim et al., 2001; Minnis et al., 2002).

The species identification by PCR in the current work has focused on the most contaminated field samples. It confirms the presence of G. pallida in Lebanon which is found in mixture with $G$. rostochiensis in most of tested lots. The origin of these two species newly detected in Lebanon is not known. However, it may have been introduced on potato tubers imported from Europe. Therefore, more work is needed to determine the distribution and the identity of the PCN in Lebanon using sequencing method. This knowledge could become essential for the assessment for nematodes management, quarantine measures and also as an extension services to encourage the farmers and the growers to adopt integrated crop production approached for the control of these species and thus to increase potato production.

\section{CONCLUSION}

The occurrence and the distribution of potato cyst nematodes in the Bekaa Valley have been studied. The current results revealed for the first time the discovery of potato cyst nematodes $G$. pallida, therefore, further investigations are needed to determine its distribution throughout potato growing area in Lebanon with different climatic conditions, cropping pattern and soil types. 


\section{REFERENCES}

Baldwin, J. G., \& Mundo-Ocampo, M. (1991). Heteroderinae, cyst- and non-cyst forming nematodes. In: Manual of Agricultural Nematology. W. R. Nickle (ed.). Marcel Dekker, Inc., New York, NY. Pp. 275-362.

Barker, K. R., \& Koenning, S. R. (1998). Developing sustainable systems for nematode management. Annu. Rev. Phytopathol., 36, 165-205.

Bates, J. A., Taylor, E. Y. J. A., Gans, P. T., \& Thomas, J. E. (2002). Determination of relative proportions of Globodera species in mixed populations of potato cyst nematodes using PCR product melting peak analysis. Molecular plant pathology, 3, 153-161.

Bulman, S. R., \& Marshall, J. W. (1997). Differentiation of Australasian potato cyst nematode $(\mathrm{PCN})$ populations using the polymerase chain reaction (PCR). New Zealand Journal of Crop and Horticultural Science, 25(2), 123-129.

Burrows, P. R., \& Perry, R. N. (1988). Two cloned DNA fragments which differentiate Globodera pallida from G. rostochiensis. Revue de Nématologie, 9, 199-200.

CABI. (2013). Globodera pallida. Crop Protection Compendium, from: www.cabi.org/cpc.

EPPO. (2004). Diagnostic protocols for regulated pests. Globodera rostochiensis and Globodera pallida. EPPO Bulletin, 34, 309-314.

Fenwick, D. W. (1949). Investigations on the emergence of larvae from the cysts of the potato-root eelworm Heterodera rostochiensis. (1). Technique and variability. Journal of Helminthology, 23, 157-170.

Fleming C. C., \& Powers, T. O. (1998). Potato cyst nematode diagnostics: morphology differential hosts and biochemical techniques. In: Marks RJ, Brodie BB, editors. Potato cyst nematodes biology, distribution and control. Wallingford: CAB International. 105. Pp.

Haydock, P. P. J., \& Evans, K. (1998). Management of potato cyst nematodes in the UK: an integrated approach? Outlook on Agriculture, 27, 253-260.

Howlett, B. J., Brownlee, A. G., Guest, D. I., Adcock, G. J. \& McFadden, G. I. (1992). The 5S ribosomal RNA gene is linked to large and small subunit ribosomal RNA genes in the oomycetes, Phytophthora vignae, P. cinnamomi, P. megasperma $f$. sp. glycinea and Saprolegnia ferax. Current genetics, 22(6), 455-46.

Ibrahim, S. K., Baldwin, J. G., Roberts, P. A., \& Hyman, B. C. (1997). Genetic variation in Nacobbus aberrans: An approach toward taxonomic resolution. Journal of Nematology, 29, 241-249.

Ibrahim, S. K., Saad, A. T., Haydock, P. P. J., \& Al-Masri, Y. (2000). Occurrence of the potato cyst nematode Globodera rostochiensis in Lebanon. Nematology, 2, 125128.

Ibrahim, S. K., Minnis, S. T., Barker, A. P., Russell, M. D., Haydock, P. P. J., Evans, K., Grove, I. G., Woods, S. R., \& Wilcox, A. (2001). Evaluation of PCR, IEF and ELISA techniques for the detection and identification of potato cyst nematodes from field soil samples in England and Wales. Pest Management Science, 57, 1068-1074.

Ibrahim, S. K., Abi Saad, H., and Mousa, N. (2004). Potato cyst nematodes Globodera spp. in Lebanon - occurrence and distribution. Lebanese Science Journal, 5(1), 25-36. 
Ibrahim, S. K., Mama, M., Israel, A., \& Ibrahim, L. (2017). The Occurrence, Distribution and Control of Potato Cyst Nematodes in Lebanon. American Journal of Agricultural Science, 4(3), 51-57.

Jones, P. W., Tylka, G. L., \& Perry, R. N. (1998). Hatching. In: Eds. Perry, R.N. \& Wright, D. J. The Physiology and Biochemistry of Free Living and Plant Parasitic Nematodes. CAB International, Wallingford, UK. Pp. 181-212.

Minnis, S. T., Haydock, P. P. J., Ibrahim, S. K., Grove, I. G., Evans, K., \& Russell, M. D. (2002). Potato cyst nematodes in England and Wales - occurrence and distribution. Annals of Applied Biology, 140, 187-195.

Potter, J. W., \& Olthof, T. A. (1993). Nematode pests in vegetable crops. In: Evans, E. K., Trudgill, D. L., Webster, J. M. (Eds.), Plant Parasitic Nematodes in Temperate Agriculture. CAB International, Wallingford, UK, Pp. 171-207.

Southey, J. F. (1986). Laboratory methods for work with plant and soil nematodes. Ministry of Agriculture, Fisheries and Food Reference Book No. 402, 202 Pp. HMSO, London, UK.

Skarbilovich, T. S. (1959). On the structure of the systematics of nematode order Tylenchida Thorne, 1949. Acta Parasitologica Polonica, 7, 117-132.

Spears, J. F. (1968). The Golden Nematode. Agriculture Handbook U.S. Department of Agriculture, No. 353. Pp. 81.

Stratford, R., Shields, R., Goldsbrough, A. P., and Fleming, C. C. (1992). Analysis of repetitive DNA sequences from potato cyst nematodes and their use as diagnostic probes. Phytopathology, 82, 881-886.

Stone, A. R. (1973). Heterodera pallida n. sp. (Nematoda: Heteroderidae), a second species of potato cyst nematode. Nematologica, 18, 591-606.

Taylor, D. P., Saad, A. T., \& Schlosser, E. (1972). Occurrence and distribution of plant parasitic nematodes in Lebanon. Plant Protection Bulletin, 20, 105-110.

White, T. J., Bruns, T., Lee, S., \& Taylor, J. (1990). Amplification and direct sequencing of fungal ribosomal RNA genes for phylogenetics. In: PCR protocols. A guide to methods and applications. Innes, M. A.; Gelfard, D. H.; Sninsky, J. J.; White, T. J. ed. San Diego, Academic Press.

Wollenweber, R. K. (1923). Effects of infestation with Globodera rostochiensis (Woll.) Behrens Ro1 on the growth of four potato cultivars. Crop Prorecr., 1, 169-179. 